\title{
News From the American School Health Association
}

The 2004 Conference of the American School Health Association (ASHA) will be in Pittsburgh, PA, October 13-17. The focus is on the school environment, especially school facilities, although other school health-related topics and research are also welcome. Applications to present are available on the web site http://www.ashaweb.org/conferences.html.

The August/September issue of Health in Action focused on Transportation Safety and the October/November issue on managing asthma in the school setting. Each issue has articles by experts in their respective fields geared to the needs of various members of the school community. This spring's issues will address substance abuse prevention and ADHD. Copies are available singly, in bulk, or through subscription. For more information, go to http://www.ashaweb.org/healthinaction.html.

Other new resources include a revised edition of Sexuality Education within Comprehensive School Health Education and a new publication Strategies for Change: A Field Guide to Social Marketing for School Health Professionals. The latter is a tool to help those seeking to implement or improve a school health program or component sell the desired changes to other members of the school community.

Susan F. Wooley, Executive Director

American School Health Association

P. O. Box 708

Kent, OH 44240-0708 USA

Ph. 330-678-1601; Fax. 330-678-4526

E-Mail: swooley@ashaweb.org 